FACTA UNIVERSITATIS

Series: Physical Education and Sport, Vol. 18, No 2, 2020, pp. 439 - 446

https://doi.org/10.22190/FUPES200611041R

Research article

\title{
THE EFFECTS OF PILATES WITH A SWISS BALL PROGRAM ON FLEXIBILITY IN FEMALE COLLEGE STUDENTS
}

\author{
UDC 796.015.132-055.2
}

\begin{abstract}
Snežana Ružić
College of Vocational Studies for the Education of Preschool Teachers and Sports Trainers, Subotica, Serbia
\end{abstract}

\begin{abstract}
Flexibility is a basic motor ability that significantly improves overall motor efficiency and reduces the possibility of muscle and joint injuries. The aim of this study was to determine the effects of Pilates exercise with a Swiss ball on flexibility development among female students. The sample of 45 participants, aged 19 to 22 years, was divided into experimental and control groups. The experimental group took part in a 12-week Pilates exercise with a Swiss ball, with a frequency of three training sessions with one hour of exercise per week. The control group was not involved in the training process. For flexibility assessment, four tests were applied (Sit and Reach, Straddle in Supine Position, Leg Lift from Supine Position and Backward Leg Lift from a Prone Position). The results of the multivariate analysis of covariance showed that there is a significant difference between the experimental and control groups. Univariate results showed significant differences in all flexibility variables. The authors conclude that the Pilates program with a ball has significantly improved the flexibility of the female students.
\end{abstract}

Key words: Pilates, Swiss Ball, Exercise Program, College, Females

\section{INTRODUCTION}

Modern fitness programs with the use of exercise accessories such as a Swiss ball can cause structural and functional adaptations that improve the fitness components of the exercisers (Kyrolainen, Santtila, Nindl, \& Vasankari, 2010). Research that has studied the effectiveness of Pilates with a Swiss ball, conducted in accordance with the appropriate health principles, in their concept of training emphasizes the importance of dynamic and static stretching exercises. Namely, training with a Swiss ball is preceded by warm-up dynamic stretching exercises, and after training, static stretching exercises are realized,

Received June 11, 2020 / Accepted June 23, 2020

Corresponding author: Snežana Ružić

College of Vocational Studies for the Education of Preschool Teachers and Sports Trainers, Banijska 67, 24000

Subotica, Serbia

Phone: + 38124547870 • E-mail: snezana59ruzic@gmail.com

(C) 2020 by University of Niš, Serbia | Creative Commons License: CC BY-NC-ND 
which significantly contributes to the development of muscle flexibility (de Oliveira, de Oliveira, \& de Almeida, 2016).

Flexibility is affected by numerous internal, external, anatomical, and other factors (Dopsaj, 1994). For these reasons this motor ability developed following an integral approach that involves the application of various techniques to achieve optimal flexibility of the soft tissue in all movement planes (Hou, Tsai, Cheng, Chung, \& Hong, 2002; National Academy of Sports Medicine-NASM, 2012). The full range of motion primarily depends on flexibility and neuromuscular efficiency regarding the ability of the nervous system to effectively control the range of motion achieved by efficient recruitment of agonists, antagonists, synergists and stabilizer muscles to produce force and to reduce force, as well as to dynamically stabilize body structures in all three planes of motion (NASM, 2012). Maximal neuromuscular efficiency is possible only if the muscular, skeletal, and neural components of movement function optimally and interdependently (NASM, 2012).

Flexibility training is a significant component of all training programs which require systematic progression based on continuous exercise. The optimal model of flexibility training consists of three phases: corrective, active, and functional flexibility (Wilson, Elliott, \& Wood, 1992; Alter, 1996; Halbertsma, Van Bulhuis, \& Goeken, 1996).

The benefits of improving flexibility are muscle imbalance correction, increase of the range of motion in the joints, excessive muscle tension reduction, joint stiffness reduction, improvement of the muscle and tendon extensibility, maintenance of the normal functional length of all muscles, improvement of the functional efficiency and neuromuscular efficiency and the reduction of risk of injury (Martin \& Morgan, 1992; Magnusson, 1998; Hou et al., 2002; Reid \& McNair, 2004; O'Sullivan, Murray, \& Sainsbury, 2009).

Previous studies have shown that flexibility does not exist as a general motor space characteristic, but is specific to each joint in the body (Merni, Balboni, Bargellini, \& Menegatti, 1981). According to Alter (1996), flexibility is specific to different groups of sports, as well as to different joints, movements and speed of movement.

In general, studies show that Pilates exercise with a Swiss ball in the population of high school students and middle-aged persons as well, can improve flexibility, especially in the torso region, due to increased range of motion compared to exercise on stable surfaces (Sekendiz, Altun, Korkusuz, \& Akin, 2007; Sekendiz, Cug, \& Korkusuz, 2010; Kloubec, 2010; Phrompaet, Paungmali, Pirunsan, \& Sitilertpisan, 2010).

However, in the existing fund of scientific knowledge, the effects of exercise on an unstable surface on the flexibility of student population are still insufficiently researched. For these reasons, this study was conducted to determine the effects of Pilates with a Swiss ball exercises on the flexibility of female college students.

\section{METHODS}

\section{The sample of participants}

The sample of participants consisted of 30 female students (aged 19-22) of the College of Vocational Studies for the Education of Preschool Teachers and Sports Trainers in Subotica. By random selection, the participants were divided into two subsamples. The first subsample consisted of participants who conducted a Pilates with a Swiss ball exercise program (EG, $n=15$ ). The second subsample consisted of a control group of participants $(C G, n=15)$ who were not exposed to any organized exercise program. 
The experimental group includes participants that received a Pilates program of exercises with a Swiss ball, while the CG participants were not involved in any type of organized exercise or training process. All of the participants were healthy, athletically inactive, and voluntarily agreed to be included in the study.

\section{The sample of measuring instruments}

The initial and final measurements of the sample characteristics and flexibility were taken. The characteristics of the sample were evaluated using the following parameters:

1. Body Height $(\mathrm{BH})$ in $\mathrm{cm}$;

2. Body Mass (BM) in $\mathrm{kg}$;

3. Body Mass Index (BMI) in $\mathrm{kg} / \mathrm{m}^{2}$.

$\mathrm{BH}$ measurements were performed with the recommendations of the International Biological Program, a guide designed by Weiner \& Lourie (1969), with a measurement accuracy of $0.1 \mathrm{~cm}$.

For flexibility assessment at teh initial and final measurement, the following tests were applied:

1. Sit and Reach $(\mathrm{cm})$.

2. Straddle in Supine Position (deg) in the following text Straddle;

3. Leg Lift from Supine Position (deg) in the following text Leg Lift;

4, Backward Leg Lift from a Prone Position (deg) in the following text Backward Leg Lift.

Procedures and layouts for all the mentioned flexibility tests are described and have been found very reliable (ICC $\geq 0.90)$ by Sporiš, Vučetić, Jovanović, Jukić, \& Omrcen (2011).

\section{Pilates with a Swiss ball program}

The experimental program for EG consisted of Pilates with Swiss ball exercises (Table 1). The number of sets and repetitions progressively increased from 1-12 weeks. Rest periods between sets progressively decreased (45, 30, 10 s., at 1-4, 5-6, 9-12 weeks, respectively).

The experimental program was conducted in the gym of the Faculty of Economics in Subotica and the sports hall of the College of Vocational Studies for the Education of Preschool Teachers and Sports Trainers in Subotica.

Table 1 Pilates with a Swiss ball program design

\begin{tabular}{lccccc}
\hline & \multicolumn{5}{c}{ Weeks } \\
\cline { 2 - 6 } Exercise & $1-2$ & $3-4$ & $5-8$ & $9-10$ & $11-12$ \\
\cline { 2 - 5 } & \multicolumn{5}{c}{ Sets/Repetitions } \\
\cline { 2 - 5 } Swiss Ball Straight Crunch & $1 / 12-15$ & $1 / 12-15$ & $2 / 10$ & $3 / 10$ & $3 / 10$ \\
Swiss Ball Back Hyperextension & $1 / 12-15$ & $1 / 12-15$ & $2 / 10$ & $3 / 10$ & $3 / 10$ \\
Swiss Ball Push-ups Feet Up & $1 / 12-15$ & $1 / 12-15$ & $2 / 10$ & $3 / 10$ & $3 / 10$ \\
Swiss Ball Wall Squat & $1 / 12-15$ & $1 / 12-15$ & $2 / 10$ & $3 / 10$ & $3 / 10$ \\
Swiss Ball Trunk Twist & $1 / 12-15$ & $1 / 12-15$ & $2 / 10$ & $3 / 10$ & $3 / 10$ \\
Swiss Ball Dips & $1 / 12-15$ & $1 / 12-15$ & $2 / 10$ & $3 / 10$ & $3 / 10$ \\
Swiss Ball Supine Bridge & $1 / 12-15$ & $1 / 12-15$ & $2 / 10$ & $3 / 10$ & $3 / 10$ \\
Swiss Ball Plank & $1 / 15 \mathrm{~s}$ & $1 / 15 \mathrm{~s}$ & $1 / 25 \mathrm{~s}$ & $1 / 40 \mathrm{~s}$ & $1 / 40 \mathrm{~s}$ \\
\hline
\end{tabular}




\section{Statistical analysis}

To determine the significance of the differences between the EG and at the initial and final measurements, a multivariate analysis of variance (MANOVA) was performed. The differences between the initial and final measurements for both the EG and CG were determined by the T-test for dependent samples. Effect size was determined by Cohen's (d) where the value of $d$ below 0.20 is considered trivial; $0.20-0.50$ small; $0.50-0.80$ moderate; 0.80-1.3 large and >1.3 very large (Cohen, 1988). Multivariate and univariate analyses of covariance (MANCOVA/ANCOVA) were used to determine the effects of the experimental program. The differences were determined at a significance level of $p<0.05$. The data were processed using the IBM SPSS ${ }^{2} 23$ statistics program, and presented in 6 tables.

\section{RESULTS}

Table 2 and Table 3 show the results of the multivariate analysis of variance which represents the difference in flexibility between the EG and CG both at the initial and final measurement.

Table 2 Differences in flexibility between the EG and CG at the initial measurement

\begin{tabular}{ccccc}
\hline \multicolumn{5}{c}{ MANOVA } \\
\hline Wilks Lambda & F & Effect - df & Error - df & $\mathrm{p}$ \\
\hline 0.734 & 2.260 & 4 & 25 & 0.091 \\
\hline
\end{tabular}

Table 3 Differences in flexibility between the EG and CG at the final measurement

\begin{tabular}{ccccc}
\hline \multicolumn{5}{c}{ MANOVA } \\
\hline Wilks Lambda & $\mathrm{F}$ & Effect - df & Error - df & $\mathrm{p}$ \\
\hline 0.721 & 2.424 & 4 & 25 & 0.075 \\
\hline
\end{tabular}

Based on the obtained results shown in the tables 2 and 3, it can be concluded that there is no significant difference in flexibility at the initial and final measurement between the subsamples because the value of $p$ is greater than 0.05 (Initial: $p=0.091$; Final: $p=0.075$ ).

Table 4 Differences in flexibility between the initial and final measurements for the EG

\begin{tabular}{|c|c|c|c|c|c|}
\hline \multirow{2}{*}{ Variable } & Ini & Fin & \multirow{2}{*}{$\mathrm{t}$} & \multirow{2}{*}{$\mathrm{p}$} & \multirow{2}{*}{$\mathrm{ES}$} \\
\hline & \multicolumn{2}{|c|}{ Mean \pm SD } & & & \\
\hline Sit and Reach $(\mathrm{cm})$ & $25.53 \pm 9.93$ & $31.20 \pm 8.01$ & 8.41 & 0.000 & 2.17 \\
\hline Straddle (deg) & $117.13 \pm 12.02$ & $122.00 \pm 8.35$ & 3.56 & 0.003 & 0.92 \\
\hline Leg Lift (deg) & $81.27 \pm 13.22$ & $87.67 \pm 15.86$ & 2.13 & 0.052 & 0.55 \\
\hline Backward Leg Lift (deg) & $31.27 \pm 10.14$ & $34.67 \pm 8.78$ & 5.59 & 0.000 & 1.44 \\
\hline
\end{tabular}

Table 4 shows the results of the T-test for dependent samples to determine the differences between the initial and final measurements of the EG. The results indicate that statistically significant differences were found for most of the analyzed variables at the level of statistical significance $(p<0.05)$. Differences with very large effects were observed in the 
variables Sit and Reach ( $p=0.000 ; E S=2.17$ ) and the Backward Leg Lift ( $p=0.000 ; E S=1.44)$. Also, a difference with a large effect was observed for the variable Straddle $(p=0.003$; $\mathrm{ES}=0.92$ ).

Table 5 Differences in flexibility between the initial and final measurements for the CG.

\begin{tabular}{|c|c|c|c|c|}
\hline \multirow{2}{*}{ Variable } & Fin & \multirow{2}{*}{$\mathrm{t}$} & \multirow{2}{*}{$\mathrm{p}$} & \multirow{2}{*}{ ES } \\
\hline & Mean \pm SD & & & \\
\hline Sit and Reach $(\mathrm{cm})$ & $25.20 \pm 9.8126 .40 \pm 9.28$ & 2.67 & 0.018 & 0.69 \\
\hline Straddle (deg) & $114.13 \pm 13.64115 .20 \pm 13.03$ & 2.54 & 0.023 & 0.66 \\
\hline Leg Lift (deg) & $84.93 \pm 18.51 \quad 84.00 \pm 19.68$ & -0.47 & 0.643 & -0.12 \\
\hline Backward Leg Lift (deg) & $26.20 \pm 6.41$ & 0.00 & 1.000 & 0.00 \\
\hline
\end{tabular}

Table 5 shows the results of the T-test test for dependent samples to determine the differences between the initial and final measurements of the CG. The results indicate that statistically significant differences were found in the two variables at the level of statistical significance $(p<0.05)$. Significant differences with moderate effects were observed in the variables of the Sit and Reach $(\mathrm{p}=0.018$; $E S=0.69)$ and in the Straddle $(\mathrm{p}=0.023 ; \mathrm{ES}=0.66)$.

Table 6 Effects of the Pilates with a Swiss ball program on flexibility - MANCOVA

\begin{tabular}{ccccc}
\hline \multicolumn{5}{c}{ MANCOVA } \\
\hline Wilks Lambda & $\mathrm{F}$ & Effect - df & Error - df & $\mathrm{p}$ \\
\hline 0.270 & 14.174 & 4 & 21 & $\mathbf{0 . 0 0 0}$ \\
\hline
\end{tabular}

Table 6 shows the results of a multivariate analysis of covariance to determine the effects of Pilates with a Swiss ball exercise program on flexibility in college female students. After including the results from the initial measurement as covariates, the results indicate that significant differences of effects between the groups at the multivariate level were present $(\mathrm{F}=8.681 ; \mathrm{p}=0.000)$. To obtain more precise information, it is necessary to perform further analyses at the univariate level.

Table 7 Effects of the Pilates with a Swiss ball program on flexibility - ANCOVA

\begin{tabular}{lccrc}
\hline Variable & EG & CG & F & p \\
& Adj. Mean & Adj. Mean & & \\
\hline Sit and Reach (cm) & 15.78 & 11.82 & 32.95 & $\mathbf{0 . 0 0 0}$ \\
Straddle (deg) & 120.09 & 117.11 & 7.80 & $\mathbf{0 . 0 1 0}$ \\
Leg Lift (deg) & 90.84 & 80.83 & 5.34 & $\mathbf{0 . 0 3 0}$ \\
Backward Leg Lift (deg) & 32.37 & 28.50 & 22.04 & $\mathbf{0 . 0 0 0}$ \\
\hline
\end{tabular}

In Table 7, the results of the univariate analysis of covariance are shown. After the neutralization and partialization of the results from the initial measurement, it can be seen that all variables in the system were responsible for the existence of differences at the multivariate level. The largest contribution was recorded for the variable Sit and Reach $(\mathrm{F}=32.95 ; \mathrm{p}=0.000)$. The variable Backward Leg Lift also makes a great contribution 
$(\mathrm{F}=22.04 ; \mathrm{p}=0.000)$. The remaining variables Straddle $(\mathrm{F}=7.80 ; \mathrm{p}=0.010)$ and Leg Lift $(\mathrm{F}=5.34 ; \mathrm{p}=0.030)$ also make a smaller but still significant contribution. Observation of adjusted means indicates that the EG accomplished better results in all the mentioned variables than the students in the CG after a 12-week period. The presented results indicate that the effect of Pilates exercises with a Swiss ball on the EG was significantly superior compared to the CG for all the variables.

\section{DISCUSSION}

The study was conducted to determine the effects of Pilates with a Swiss ball exercises on the flexibility in college female students.

According to the obtained results, it can be concluded that in the EG which took part in a Pilates exercise program with a Swiss ball, there were significant differences between the initial and final measurement, and also significant effects after a 12-week period on flexibility among female college students.

The positive effects of Pilates training programs which used a Swiss ball as a prop on flexibility has been confirmed in previous research providing among other things, a higher awareness of women's health and physical fitness, and helping in the prevention of chronic and cardiovascular diseases, a reduction in the degree of non-structural scoliosis, increased flexibility and decreased pain, enhanced control-mobility of the trunk and pelvic segments, prevention and attenuation of the predisposition to axial musculoskeletal injury, an improvement in core strength training, in dynamic balance and EMG neuronal activity (Cosio-Lima, Reynolds, Winter, Paolone, \& Jones, 2003; Sekendiz et al., 2010; Phrompaet et al., 2011; de Araújo et al., 2012; Kao, Liou, Huang, Tsai, \& Wang, 2015; Kibar et al., 2016). Exercising on a Swiss balls due to an unstable surface affects proprioceptive neuromuscular facilitation (PNF) and generates greater muscle activity compared to similar movements on a stable surface and also effectively develops muscle ability (Cosio-Lima et al., 2003; Carter, Beam, McMahan, Barr, \& Brown, 2006; Sekendiz et al., 2007, 2010; Kloubec, 2010; Smith, Mitcheltree, Kieffer, \& Miller, 2018). Exercising on a Swiss ball can improve flexibility, especially of the torso region, due to the increase in movement amplitude compared to exercise on stable surfaces (Sekendiz et al., 2007, 2010; Kloubec, 2010; Phrompaet et al., 2010).

Training processes should be programmed in such a way that their impact and effect can cause optimal transformation in flexibility. Based on the obtained results, it can be concluded that Pilates exercise with a Swiss ball after 12 weeks contribute a positive effect on flexibility in female college subjects, aged between 19 and 22 years. If the goal is to improve flexibility in this population, the applied exercise program with a similar dose of exercise volume and intensity can be used.

\section{CONCLUSION}

The 12-week Pilates exercise program with a Swiss ball led to significant improvement in all flexibility variables. It can be concluded that Pilates with a Swiss ball program as a specific type of exercise on an unstable surface induces greater muscle elasticity and hip joint movement amplitudes and as such have positive effects on overall flexibility. These findings can provide conceptual guidance for designing similar exercise programs for female college students, also for comparing results with previous and future studies. 


\section{REFERENCES}

Alter, M.J. (1996). Science of flexibility. Champaing, IL: Human Kinetics.

Carter, J.M., Beam, W.C., McMahan, S.G., Barr, M.L., \& Brown, L.E. (2006). The effects of stability ball training on spinal stability in sedentary individuals. The Journal of Strength \& Conditioning Research, 20(2), 429-435.

Cosio-Lima, L.M., Reynolds, K.L., Winter, C., Paolone,V., \& Jones, M.T. (2003). Effects of physioball and conventional floor exercises on early phase adaptations in back and abdominal core stability and balance in women. Journal of Strength and Conditioning Research, 17(4), 721-725.

de Araújo, M.E.A., da Silva, E.B., Bragade Mello, D.B., Cader, S.A., Salgado, A.S.I., \& Dantas, E.H.M. (2012). The effectiveness of the Pilates method: reducing the degree of non-structural scoliosis, and improving flexibility and pain in female college students. Journal of Bodywork and Movement Therapies, 16(2), 191-198.

de Oliveira, L.C., de Oliveira, R.G. \& de Almeida Pires-Oliveira, D.A. (2016). Comparison between static stretching and the Pilates method on the flexibility of older women. Journal of Bodywork and Movement Therapies, 20(4), 800-806.

Dopsaj, M. (1994). Extent of flexibility among athletes in different sports games: Soccer, volleyball, basketball and handball. Facta Universitatis Series Physical Education and Sport, 1(1), 51-60.

Halbertsma, J.P., Van Bulhuis, A.I., \& Goeken, L.N. (1996). Sport stretching: Effect on passive muscle stiffness of short hamstrings. The Archives of Physical Medicine and Rehabilitation, 77(7), 688-692.

Hou, C.R., Tsai, L.C., Cheng, K.F., Chung, K.C., \& Hong, C.Z. (2002). Immediate effects of various therapeutic modalities on cervical myofascial pain and trigger-point sensitivity. The Archives of Physical Medicine and Rehabilitation, 83(10), 1406-1414.

Kao, Y.H., Liou, T.H., Huang, Y.C., Tsai, Y.W., \& Wang, K.M. (2015). Effects of a 12-week Pilates course on lower limb muscle strength and trunk flexibility in women living in the community. Health Care for Women International, 36(3), 303-319.

Kibar, S., Yardimci, F.Ö., Evcik, D., Ay, S., Alhan, A., Manço, M., et al. (2016). Can a pilates exercise program be effective on balance, flexibility and muscle endurance? A randomized controlled trial. The Journal of sports medicine and physical fitness, 56(10), 1139-1146.

Kloubec, J.A. (2010). Pilates for improvement of muscle endurance, flexibility, balance, and posture. Journal of Strength \& Conditioning Research, 24(3), 661-667.

Kyrolainen, H., Santtila, M., Nindl, B.C., \& Vasankari, T. (2010). Physical fitness profiles of young men: associations between physical fitness, obesity and health. Sports Medicine, 40(11), 907-920.

Magnusson, S.P. (1998.). Passive properties of human skeletal muscle during stretch maneuvers. The Scandinavian Journal of Medicine \& Science in Sports, 8(2), 65-77.

Martin, P.E., \& Morgan, D.W. (1992.). Biomechanical considerations for economical walking and running. Medicine \& Science in Sports \& Exercise, 24(4), 467-474.

Merni, F., Balboni, M., Bargellini, S., Menegatti, G. (1981). Differences in mails and femails in joint movement range during growth. Medicine and Sport, 15, 168-175.

National Academy of Sports Medicine-NASM. (2012). NASM essentials of personal fitness training. UK: Lippincott Williams \& Wilkins.

O'Sullivan, K., Murray, E., \& Sainsbury, D. (2009.). The effect of warm-up, static stretching and dynamic stretching on hamstring flexibility in previously injured subjects. BMC Journal of Musculoskeletal Disorders and Treatment, 10(1), 1-9.

Phrompaet, S., Paungmali, A., Pirunsan, U., \& Sitilertpisan, P. (2011). Effects of pilates training on lumbo-pelvic stability and flexibility. Asian Journal of Sports Medicine, 2(1), 16-22.

Reid, D.A., \& McNair, P.J. (2004). Passive force, angle, and stiffness changes after stretching of hamstring muscles. Medicine \& Science in Sports \& Exercise, 36(11), 1944-1948.

Sekendiz, B., Altun, O., Korkusuz, F., \& Akin, A. (2007). Effects of Pilates exercise on trunk strength, endurance and flexibility in sedentary adult females. Journal of Bodywork and Movement Therapies, 11(4), 318-326.

Sekendiz, B., Cug, M., \& Korkusuz, F. (2010). Effects of Swiss-ball core strength training on strength, endurance, flexibility and balance in sedentary women. Journal of Strength and Conditioning Research, 24(11),3032-3040.

Smith, M., Mitcheltree, T., Kieffer, S., \& Miller, D. (2018) Six-week pilates program improved postural stability, balance, and isometric back strength in college-aged athletes. International Journal of Exercise Science: Conference Proceedings, 9(6), 119.

Sporiš, G., Vučetić, V., Jovanović, M., Jukić, I., \& Omrcen, D. (2011). Reliability and factorial validity of flexibility tests for team sports. The Journal of Strength \& Conditioning Research, 25(4), 1168-1176.

Weiner J., \& Lourie J. (1969). Human biology, a guide to field methods, international biological programe. Oxford-Edinburgh: Blackwell Scientific Publications.

Wilson, G.J., Elliott, B.C., \& Wood, G.A. (1992). Stretch shorten cycle performance enhancement through flexibility training. Medicine \& Science in Sports \& Exercise, 24(1), 116-123. 


\section{EFEKTI PILATESA PROGRAMA SA ŠVAJCARSKOM LOPTOM NA FLEKSIBILNOST STUDENATKINJA}

Fleksibilnost je osnovna motorička sposobnost koja značajno poboljšava ukupnu motoričku efikasnost i smanjuje mogućnost povreda mišića i zglobova. Cilj ove studije bio je da se utvrde efekti pilates vežbanja sa švajcarskom loptom na razvoj fleksibilnosti studentkinja. Uzorak od 45 učesnika, uzrasta od 19 do 22 godine, podeljen je u eksperimentalnu i kontrolnu grupu. Eksperimentalna grupa sprovodila je 12-nedeljne Pilates vežbe sa švajcarskom loptom, sa frekvencijom od tri jednosatna treninga nedeljno. Kontrolna grupa nije bila uključena u trenažni proces. U proceni fleksibilnosti primenjena su četiri testa (sed i doseg, položaj raznoženja iz ležećeg položaja na leđima, odizanje nogu napred iz ležećeg položaja na leđima i odizanje nogu unazad iz ležećeg položaja na stomaku). Rezultatima multivarijantne analize kovarijance utvrđeno je da postoji značajna razlika između eksperimentalne i kontrolne grupe. Univarijantnom analizom utvrđene su značajne razlike u svim varijablama fleksibilnosti. Autori zaključuju da je Pilates program vežbanja sa švajcarskom loptom značajno poboljšao fleksibilnost studentkinja.

Ključne reči: pilates, švajcarska lopta, program vežbanja, koledž, žene 